\section{Clinton's adviser foresees a new breed of civic scientist}

Researchers must be "global citizen scientists" - aware of both new knowledge and the needs of society - according to Neal Lane, science adviser to US President Bill Clinton.

In a speech delivered on his behalf by Bruce Alberts, president of the National Academy of Sciences, Lane said that "in their new capacity of 'civic scientist', scientists and engineers must step outside of their campuses, laboratories and institutes to engage in an active dialogue with their fellow citizens".

Scientists need to look beyond intriguing research questions and examine the ways in which new scientific knowledge may be best used by society, Lane said.

This, he added, means that scientists need to communicate with - and listen to - the public. "There is a great need for the public to have a better understanding of science. But there is an equally great need for scientists to have a better understanding of the public."

\title{
Young scientists seek help from Unesco
}

Young scientists have called on Unesco to create a body to represent their views. The International Forum of Young Scientists (IFYS) wants a forum for discussing general issues and challenges to science.

The group feels that a permanent body would keep young scientists in contact with both Unesco and the International Council for Science. Unesco directorgeneral Federico Mayor, who met with an IFYS delegation, reacted positively to the request and said the prospects for such a body were "very good".

"This is one of the things I wish the World Conference on Science to take into account. I think it is a good initiative and I have told young scientists that we must try to have a permanent interaction."

Mayor says he will "consider whether a young people's forum could be a

permanent representative in follow-ups to the World Conference.

"The young people should not be silent and should be making some noise." He envisaged interaction at regional and subregional levels via the Internet.

More than 150 young scientists and students from 54 countries met at the three-day forum organized by Unesco to let the "new generation" of scientists contribute to the conference. Their final recommendations include suggestions that: scientists try harder to inform the public about research and its implications; science education at all levels be strengthened; education presents science in a cross-disciplinary manner; ethical aspects be considered in all scientific undertakings and education programmes; and that scientists take more responsibility to help less developed countries.

Nobel laureate Leon Lederman warned against treating young scientists as "cheap labour", saying "we often talk about the responsibility of scientists towards society ... a big part of our responsibility is to see how young scientists develop". Lederman urged scientists to communicate the importance of science funding as well as the need for science literacy.

Meanwhile, a Unesco survey of young scientists found that their main concern was over the correct use of science to achieve peace and development.

Natasha Loder

\section{Research 'must aid fight against poverty'}

M. S. Swaminathan, one of the architects of the Green Revolution, has called for the eradication of poverty to be given the highest priority by national governments and international organizations.

In a keynote address on the opening day of the World Conference on Science, Swaminathan said that poverty eradication is the key to meeting basic human needs. "Poverty is the root cause of hunger, lack of shelter and access to clean water, illiteracy, ill health and other forms of human deprivation," he said.

He showed how many applications of modern science, its management and its administration, have contributed to poverty. But he said that there is little doubt that science has a crucial role to play in poverty eradication - both in the way it is applied and in the way it is used to empower the poor to help themselves.

An example of the first, he said, is the genetic modification of agriculture. An example of the second is the way science enables farmers to manage land and livestock better by training them to gather and make use of computer-based data on soil, pests and water. This helps them to understand the causes of specific problems as well as to think of ways of resolving them.

In a wide-ranging address, Swaminathan pointed out that no international summit or convention in recent times has addressed the issue of poverty exclusively. He added that the goals of many such gatherings will not be reached without simultaneously addressing poverty issues.

Three such issues, according to Swaminathan, are: establishing an international centre for cooperation in water management; a global programme to fight maternal and fetal malnutrition to cut the number of children born with low birth weights; and a scheme to eliminate hidden hunger caused by the absence of micronutrients in the diet.

Contaminated drinking water contributes to ten per cent of diseases in developing countries. And in 1996, 1.8 billion low- and middle-income households lacked access to sanitary facilities. But, with global per capita water supplies 30 per cent lower than 25 years ago, and continuing to decline, Swaminathan predicted that conflicts over water would grow unless active measures were taken to resolve potential disputes.

Similar measures are needed to tackle malnutrition in many countries, according to Swaminathan. Up to half of the children in several developing countries have low birth weight because their mothers are undernourished, he said. "Millions of children will continue to be born for mere existence and not for happiness if this area of nutrition continues to receive inadequate attention."

But poverty, said Swaminathan, had another cause: lack of access to knowledge, or what he described as "orphans remaining orphans". One example, he said, was the "technological apartheid" being created by the increasing amount of science being covered by intellectual property rights.

This is closing off sources of knowledge to the poor, and is inequitable. For example, the lack of recognition by the World Trade Organization (WTO) of the "invaluable contributions of tribal and rural families to genetic resources conservation" remains a source of concern. He called on the WTO's member states to correct this by bringing the Trade Related Intellectual Property Rights agreement in line with the United Nations Convention on Biological Diversity.

The world's science academies, said Swaminathan, have a duty to help the rural poor. "A priority task for the Inter-Academy Center proposed by Bruce Alberts [president of the US National Academy of Sciences] should be the closing of the vast knowledge and skill gap between rich and poor nations and between the rich and poor within nations."

Any anti-poverty policy, said Swaminathan, had to emphasize access to science for the women of the developing world. Some of the blame, he suggested, lay at the door of science education, which tended to be biased towards men.

E.M. 